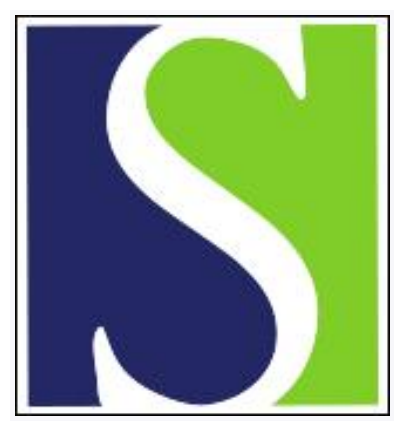

Scand J Work Environ Health 1993;19(4):271-276

https://doi.org/10.5271/sjweh.1474

Issue date: 01 Aug 1993

Digital arterial responsiveness to cold in healthy men, vibration white finger and primary Raynaud's phenomenon. by Bovenzi $\mathrm{M}$

Affiliation: Institute of Occupational Health, University of Trieste, Italy.

This article in PubMed: www.ncbi.nlm.nih.gov/pubmed/8235516

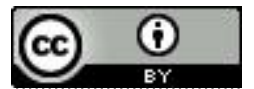




\title{
Digital arterial responsiveness to cold in healthy men, vibration white finger and primary Raynaud's phenomenon
}

\author{
by Massimo Bovenzi, MD ${ }^{1}$
}

\begin{abstract}
BOVENZI M. Digital arterial responsiveness to cold in healthy men, vibration white finger and primary Raynaud's phenomenon. Scand J Work Environ Health 1993;19:271-6. Finger systolic pressure (FSP) was measured during a standardized cold test in 291 healthy male subjects divided into five age groups. The age groups showed no difference in the change in FSP (FSP\%) after cold provocation at 15 and $10^{\circ} \mathrm{C}$. In the entire population, the lower normal limits of FSP\% were estimated as $76 \%$ at $15^{\circ} \mathrm{C}$ and $63 \%$ at $10^{\circ} \mathrm{C}$. When a discriminating threshold of FSP\% ${ }_{10}^{\circ}<60 \%$ was applied to the results of the cold test of 31 referents, 65 chain saw workers with or without vibration-induced white finger (VWF), and 20 male patients with primary Raynaud's phenomenon (PRP), the sensitivity of the test to detect digital vasospasm was $84 \%$ for VWF and $95 \%$ for PRP. In the chain-saw worker group, the positive and negative predictive values of the cold test were $94 \%$. Therefore the measurement of FSP during cold provocation can be considered a useful laboratory test to confirm Raynaud's symptoms objectively in both groups and individuals.
\end{abstract}

Key terms: cold provocation test, finger systolic pressure, predictive value, sensitivity, specificity, vasospastic syndromes.

Several laboratory tests have been proposed to detect digital vasospasm in subjects affected with primary or secondary Raynaud's phenomenon. Most of these tests are based on cold provocation and the measurement of some indices of circulatory function before and after local cooling of fingers and hands with thermometric, laser-Doppler, or plethysmographic methods $(1-3)$. In occupational medicine, the measurement of finger systolic pressure (FSP) is considered a useful vascular test to reveal digital arterial hyperresponsiveness to cold in workers exposed to chemical and physical agents known to cause vasospastic syndromes, such as hand-arm vibration, extreme cold environment, vinyl chloride, and arsenic (4-6). However, owing to the wide variability of the response of the digital arteries to cold and to the shortage of reference data from normal individuals, different estimates of the accuracy of FSP measurement in the objective diagnosis of Raynaud's phenomenon have been reported by various authors $(1,3,4,7,8)$.

In this study FSP measurement during local cooling was performed in a large sample of healthy male subjects of working age to investigate the physiological reaction to cold in the digital arteries of normal individuals. Standardized laboratory methods for FSP measurement and cold provocation were used to obtain normative values for cold-induced chang-

1 Institute of Occupational Health, University of Trieste, Trieste, Italy.

Reprint requests to: Dr M Bovenzi, Istituto di Medicina del Lavoro, Università di Trieste, c/o Centro Tumori, Via della Pietà 19, I-34129 Trieste, Italy. es in FSP in healthy subjects. In addition, the sensitivity of the cold test to detect digital vasospasm was assessed in a group of men affected with primary Raynaud's phenomenon and in a population of chainsaw workers at risk for vibration-induced white finger. For this latter group, the positive and negative predictive values of the cold test were also evaluated.

\section{Subjects and methods}

\section{Subjects}

Two hundred and ninety-one healthy men, aged 20 to 69 years, underwent a medical interview and a complete clinical examination at the vascular laboratory of the Institute of Occupational Health, Trieste. None of the subjects had any cardiovascular or neurological abnormalities in a physical examination, and none of them were on any form of medication. All of them had a negative family history of cold hypersensitivity in the hands or of constitutional white fingers.

The study population was divided into the following five groups according to age: $20-29$ years $(\mathrm{N}=44), 30-39$ years $(\mathrm{N}=64), 40-49$ years $(\mathrm{N}=$ $76), 50-59$ years $(\mathrm{N}=72)$, and $60-69$ years $(\mathrm{N}=$ 35). Smoking and drinking habits, expressed in terms of grams of tobacco and alcohol per day, were not different among the age groups. White-collar workers (clerks, officers) represented about one-third of the sample, while the remaining subjects were bluecollar workers (construction workers, mechanics, electricians) not exposed to hand-arm vibration or other agents causing Raynaud's phenomenon of oc- 
cupational origin. A group of 65 forestry workers using chain saws (mean age 44.7 years) and a reference group of 31 manual workers not exposed to vibration (mean age 44.0 years) were also examined. The duration of exposure to chain-saw vibration averaged 11.3 years in the forestry worker group. Digital vasospastic symptoms [ie, vibration-induced white finger (VWF)] were rated according to the Stockholm Workshop scale (9). Finally, 20 male patients diagnosed consecutively as having primary Raynaud's phenomenon (mean age 37.1 years) were included in the study. The diagnosis of primary Raynaud's phenomenon was made according to the clinical criteria suggested by Allen \& Brown (10). The patients with primary Raynaud's phenomenon had bilateral involvement of most fingers, and $40 \%$ of them had attacks of both fingers and toes.

\section{Finger systolic pressure and cold provocation}

The cold test was performed with the subject in a supine position after a rest of $30 \mathrm{~min}$ in a thermostated room with an ambient temperature of $22-23^{\circ} \mathrm{C}$. The subjects wore light clothing during the test. Digital systolic blood pressure was measured after cold provocation of a test finger according to the cooling technique proposed by Nielsen \& Lassen (11). A double-inlet plastic cuff for both air filling and water perfusion was placed around the middle phalanx of the third left finger of the healthy referents and the chain-saw workers without VWF. In the subjects with VWF or primary Raynaud's phenomenon, the most affected digit was cooled. The test finger was thermostated with water circulating at 30,15 , or $10^{\circ} \mathrm{C}$ by using a digit cooling system (Medimatic A/S, Copenhagen, Denmark). Two air-filled cuffs were applied on the proximal phalanx of the test finger (for ischemia during cooling) and on the middle phalanx of a reference finger (usually the fourth finger). The cold test was performed by pressurizing the air cuffs at a suprasystolic level $(210 \mathrm{~mm} \mathrm{Hg}$ or $\approx 28.0 \mathrm{kPa})$ and perfusing the water cuff initially at $30^{\circ} \mathrm{C}$ and then at 15 and $10^{\circ} \mathrm{C}$. After 5 min of ischemic cooling, the digital systolic blood pressure was measured on the test and reference fingers by a plethysmographic technique. Arm systolic pressure was measured by a mercury sphygmomanometer using a standard cuff. For each subject, the following two pressure indices were derived from the arm and finger systolic pressures:

1. Change of FSP in the test finger at 15 or $10^{\circ} \mathrm{C}$ $\left(\mathrm{FSP}_{\text {test, } x^{\circ}}\right)$ as a percentage of the pressure at $30^{\circ} \mathrm{C}$ $\left(\mathrm{FSP}_{\mathrm{test}, 3^{\circ}}{ }^{\text {test }, x^{\circ}}\right)$, corrected for the change of pressure in the reference finger during the cold test $\left(\mathrm{FSP}_{\text {ref } 30^{\circ}}\right.$ - FSP $_{\text {ref }, x^{\circ}}$ ):

$$
\begin{aligned}
& \mathrm{FSP} \%_{x^{\circ}}=\left(\mathrm{FSP}_{\text {test }, x^{\circ}} \cdot 100\right) /\left[\mathrm{FSP}_{\text {tet }, 30^{\circ}}-\left(\mathrm{FSP}_{\text {ref }, 30^{\circ}}\right.\right. \\
& \left.\left.-\mathrm{FSP}_{\text {ref }, x^{\circ}}\right)\right] .
\end{aligned}
$$

2. Digital pressure index in the test finger at 30,15 , and $10^{\circ} \mathrm{C}\left(\mathrm{DPI}_{x^{\circ}}\right)$, calculated as the ratio of FSP to arm systolic pressure $\left(\mathrm{ASP}_{x^{\circ}}\right)$ :

$$
\mathrm{DPI}_{x^{\circ}}=\left(\mathrm{FSP}_{\text {test }, x^{0}} \cdot 100\right) / \mathrm{ASP}_{x^{\circ}}
$$

In order to avoid nicotine-induced vasoconstrictive effects on the digital arteries, tobacco users had refrained from smoking for at least $4 \mathrm{~h}$ before the testing.

\section{Statistical analysis}

The FSP measurements were expressed as means and standard deviations or as medians and ranges. The lower normal limits of the FSP parameters were calculated as the mean - $\left(\mathrm{SD} \cdot t_{0.01}\right)$, where $\mathrm{SD}$ is the standard deviation and $t$ is the percentile of the Student's $t$ distribution. The differences among the mean values were tested by an analysis of variance and covariance. Two or $k$ independent samples of nonnormally distributed data were compared by the Mann-Whitney test and the Kruskal-Wallis test, respectively. In both the parametric and nonparametric one-way analysis of variance, multiple comparison tests were used to compare pairs of groups. A P-value of 0.05 (two-sided) was chosen as the limit of statistical significance. The sensitivity, specificity, and predictive value of the cold test to diagnose Raynaud's phenomenon objectively were evaluated by the receiver operating characteristics (ROC) analysis.

\section{Results}

\section{Cold test of the healthy male subjects}

Table 1 shows that among the healthy men the FSP in the test and reference fingers after warming to $30^{\circ} \mathrm{C}$ was lower in the younger subjects $(20-29$ years) than in the older ones (50-69 years) $(\mathrm{P}<0.05)$. However, when the FSP was normalized to the arm systolic pressure, the digital pressure index $\left(\mathrm{DPI}_{30^{\circ}}\right)$ was similar in all of the groups. Within each age group, no difference was observed between the FSP measured on the test and reference fingers. No relation was found between $\mathrm{FSP}_{30^{\circ}}$ of the test finger and smoking and drinking habits. Finger cooling provoked a significant decrease in FSP in the test finger. In the whole group, the reduction in FSP averaged $2.3 \mathrm{~mm} \mathrm{Hg}(\approx 0.31 \mathrm{kPa})$ at $15^{\circ} \mathrm{C}$ and $7.6 \mathrm{~mm}$ $\mathrm{Hg}(\approx 1.01 \mathrm{kPa})$ at $10^{\circ} \mathrm{C}(\mathrm{P}<0.005)$. Table 2 presents the mean values, standard deviations, and lower normal limits for FSP\%, DPI ${ }_{15^{\circ}}$, and DPI ${ }_{10^{\circ}}$ The analysis of variance showed no difference in the pressure parameters among the various age groups, except for $\mathrm{DPI}_{10^{\circ}}(\mathrm{P}<0.05)$. In the entire group, the lower normal limits for $\mathrm{FSP} \%_{15^{\circ}}$ and FSP $\%_{10^{\circ}}$ were 76 and $63 \%$, respectively. After control for age, the FSP parameters at $10^{\circ} \mathrm{C}$ were found to be lower for the smokers than for the nonsmokers (table 3), but the 
difference was significant only for $\mathrm{DPI}_{10^{\circ}}(\mathrm{P}<0.05)$. Among the smokers, a significant inverse relationship was observed between the decrease in FSP\% and $\mathrm{DPI}_{10^{\circ}}$ and daily tobacco consumption $(\mathrm{P}<0.01)$.

Cold test of the vibration-exposed workers and the patients with primary Raynaud's phenomenon

Table 4 shows the results of the cold test for the 31 manual workers in the reference group, the 65 chainsaw workers with or without VWF, and the 20 pa- tients affected with primary Raynaud's phenomenon. Among the chain-saw operators, the prevalence of VWF was $29.2 \%$. Of the 19 forestry workers suffering from VWF, seven $(10.7 \%)$ were in stage 1 , seven $(10.7 \%)$ were in stage 2 , and five $(7.7 \%)$ were in stage 3 according to the classification of the Stockholm Workshop (9). The latency interval for VWF (ie, the length of exposure to vibration before the first episode of finger blanching) averaged 9.4 (SD 6.8) years. Finger cooling to 15 and $10^{\circ} \mathrm{C}$ caused a sig-

Table 1. Arm and finger blood pressure in the healthy male subjects during the provocation test with water at $30^{\circ} \mathrm{C} .(\mathrm{ASP}=\operatorname{arm}$ systolic pressure, $F_{S P}=$ finger systolic pressure in the test finger, $F S P_{\text {ref }}=$ finger systolic pressure in the reference finger, $\mathrm{DPI}=$ digital pressure index, calculated as the ratio of $\mathrm{FSP}_{\mathrm{t}}$ to $\mathrm{ASP}$ )

\begin{tabular}{|c|c|c|c|c|c|c|c|c|c|}
\hline \multirow{2}{*}{$\begin{array}{l}\text { Age } \\
\text { group } \\
\text { (years) }\end{array}$} & \multirow{2}{*}{$\begin{array}{c}\text { Number } \\
\text { of } \\
\text { subjects }\end{array}$} & \multicolumn{2}{|c|}{$\begin{array}{c}\mathrm{ASP}_{30^{\circ}} \\
(\mathrm{mmHg})^{\mathrm{a}}\end{array}$} & \multicolumn{2}{|c|}{$\begin{array}{l}\mathrm{FSP}_{\mathrm{t}, 30^{\circ}} \\
(\mathrm{mmHg})^{\mathrm{a}}\end{array}$} & \multicolumn{2}{|c|}{$\begin{array}{l}\text { FSP }_{\text {ref, }} 30^{\circ} \\
(\mathrm{mmH})^{\mathrm{a}}\end{array}$} & \multicolumn{2}{|c|}{$\begin{array}{c}\mathrm{DPl}_{30^{\circ}} \\
(\%)\end{array}$} \\
\hline & & Mean & SD & Mean & SD & Mean & SD & Mean & $S D$ \\
\hline $\begin{array}{l}20-29 \\
30-39 \\
40-49 \\
50-59 \\
60-69\end{array}$ & $\begin{array}{l}44 \\
64 \\
76 \\
72 \\
35\end{array}$ & $\begin{array}{l}127 \\
132 \\
131 \\
139 \\
142^{*}\end{array}$ & $\begin{array}{l}15.4 \\
15.5 \\
13.9 \\
19.4 \\
16.0\end{array}$ & $\begin{array}{l}113 \\
120 \\
122 \\
129 \\
128^{\star}\end{array}$ & $\begin{array}{l}18.9 \\
20.4 \\
17.5 \\
22.2 \\
21.8\end{array}$ & $\begin{array}{l}114 \\
121 \\
122 \\
130 \\
128^{*}\end{array}$ & $\begin{array}{l}18.4 \\
19.4 \\
18.7 \\
22.1 \\
19.8\end{array}$ & $\begin{array}{l}88.5 \\
91.3 \\
93.7 \\
92.7 \\
90.8\end{array}$ & $\begin{array}{l}12.4 \\
12.8 \\
13.4 \\
12.8 \\
13.6\end{array}$ \\
\hline $20-69$ & 291 & 134 & 16.8 & 122 & 20.7 & 123 & 20.4 & 91.8 & 13.0 \\
\hline
\end{tabular}

a $1 \mathrm{mmHg} \approx 133 \mathrm{kPa}$.

* $P<0.01$ (one-way analysis of variance for the difference among age groups).

Table 2. Finger blood pressure measured during cold provocation at 15 and $10^{\circ} \mathrm{C}$. (FSP $\%=$ finger systolic pressure in the test finger at $15^{\circ} \mathrm{C}$ and $10^{\circ} \mathrm{C}$ as a percentage of the pressure at $30^{\circ} \mathrm{C}, \mathrm{DPI}=$ digital pressure index for the test finger at $15^{\circ} \mathrm{C}$ and $10^{\circ} \mathrm{C}$, calculated as the ratio of finger systolic pressure to arm systolic pressure)

\begin{tabular}{|c|c|c|c|c|c|c|c|c|c|c|c|c|c|}
\hline & & & $\begin{array}{l}\text { SP\% } \\
(\%)\end{array}$ & & & $\begin{array}{c}\mathrm{DPI}_{15} \\
(\%)\end{array}$ & & & $\begin{array}{c}\text { SP } \%_{1} \\
(\%)\end{array}$ & & & $\begin{array}{c}\mathrm{DPl}_{10^{\circ}} \\
(\%)\end{array}$ & \\
\hline (years) & & & & Lower & & & Lower & & & Lower & & & Lower \\
\hline $\begin{array}{l}20-29 \\
30-39 \\
40-49 \\
50-59 \\
60-69\end{array}$ & $\begin{array}{l}(N=44) \\
(N=64) \\
(N=76) \\
(N=72) \\
(N=35)\end{array}$ & $\begin{array}{l}96.1 \\
97.6 \\
97.3 \\
99.3 \\
97.9\end{array}$ & $\begin{array}{l}7.0 \\
8.9 \\
8.9 \\
8.7 \\
4.8\end{array}$ & $\begin{array}{l}77.2 \\
73.9 \\
73.7 \\
76.2 \\
84.8\end{array}$ & $\begin{array}{l}86.0 \\
91.3 \\
92.9 \\
93.7 \\
88.7\end{array}$ & $\begin{array}{l}12.7 \\
17.0 \\
14.6 \\
14.2 \\
13.0\end{array}$ & $\begin{array}{l}51.8 \\
46.2 \\
54.3 \\
56.1 \\
52.3\end{array}$ & $\begin{array}{l}92.9 \\
95.4 \\
94.3 \\
94.8 \\
89.5\end{array}$ & $\begin{array}{l}11.4 \\
11.4 \\
10.7 \\
12.7 \\
13.7\end{array}$ & $\begin{array}{l}62.2 \\
65.1 \\
66.0 \\
61.2 \\
52.2\end{array}$ & $\begin{array}{l}82.7 \\
89.1 \\
90.5 \\
89.1 \\
78.8\end{array}$ & $\begin{array}{l}14.3 \\
19.5 \\
15.0 \\
16.9 \\
18.6\end{array}$ & $\begin{array}{l}44.2 \\
37.3 \\
50.8 \\
44.4 \\
28.1\end{array}$ \\
\hline $20-69$ & $(\mathrm{~N}=291)$ & 97.7 & 8.3 & 76.1 & 91.2 & 14.7 & 52.9 & 93.8 & 11.9 & 62.8 & 87.3 & 17.3 & 42.3 \\
\hline
\end{tabular}

a Lower normal limit $=$ mean $-\left(S D \cdot t_{n n 1}\right)$.

Table 3. Systolic blood pressure during the cold test in the sample of healthy male subjects according to smoking habit. [FSP $\%=$ finger systolic pressure in the test finger at $15^{\circ} \mathrm{C}$ and $10^{\circ} \mathrm{C}$ as a percentage of the pressure at $30^{\circ} \mathrm{C}\left(\mathrm{FSP}, 30^{\circ}\right)$, $\mathrm{DPI}=$ digital pressure index in the test finger at $30^{\circ} \mathrm{C}, 15^{\circ} \mathrm{C}$ and $10^{\circ} \mathrm{C}$, calculated as the ratio of finger systolic pressure to arm systolic pressure, SE = standard error]

\begin{tabular}{|c|c|c|c|c|c|c|c|c|c|c|c|c|}
\hline & \multicolumn{2}{|c|}{$\begin{array}{l}\mathrm{FSP}_{\mathrm{t}, 30^{\circ}} \\
(\mathrm{mmHg})^{\mathrm{a}}\end{array}$} & \multicolumn{2}{|c|}{$\begin{array}{c}\mathrm{DPI}_{30^{\circ}} \\
(\%)\end{array}$} & \multicolumn{2}{|c|}{$\begin{array}{l}\text { FSP } \%{ }_{15}^{\circ} \\
(\%)\end{array}$} & \multicolumn{2}{|c|}{$\begin{array}{c}\mathrm{DPl}_{15} \\
(\%)\end{array}$} & \multicolumn{2}{|c|}{$\begin{array}{c}\text { FSP } \%{ }_{10}^{\circ} \\
(\%)\end{array}$} & \multicolumn{2}{|c|}{$\begin{array}{l}\mathrm{DPl}_{10} \\
(\%)\end{array}$} \\
\hline & Mean $^{b}$ & SE & Mean' & SE & Mean'b & SE & Mean' & SE & Mean $^{b}$ & SE & Mean'b & SE \\
\hline $\begin{array}{l}\text { Nonsmokers }(N=134) \\
\text { Smokers }(N=157)\end{array}$ & $\begin{array}{l}125 \\
121\end{array}$ & $\begin{array}{l}1.7 \\
1.6\end{array}$ & $\begin{array}{l}92.4 \\
91.2\end{array}$ & $\begin{array}{l}1.1 \\
1.0\end{array}$ & $\begin{array}{l}97.8 \\
97.7\end{array}$ & $\begin{array}{l}0.8 \\
0.7\end{array}$ & $\begin{array}{l}92.3 \\
90.5\end{array}$ & $\begin{array}{l}1.4 \\
1.3\end{array}$ & $\begin{array}{l}95.0 \\
92.9\end{array}$ & $\begin{array}{l}1.0 \\
0.9\end{array}$ & $\begin{array}{l}89.6 \\
85.3^{\star}\end{array}$ & $\begin{array}{l}1.5 \\
1.4\end{array}$ \\
\hline
\end{tabular}

a $1 \mathrm{mmHg} \approx 133 \mathrm{kPa}$.

b Age-adjusted.

* $P=0.035$. 
Table 4. Results of the cold test at $15^{\circ} \mathrm{C}$ and $10^{\circ} \mathrm{C}$ for the referents, the chain-saw workers with or without vibration-induced white finger (VWF), and the patients affected with primary Raynaud's phenomenon. (FSP $\%=$ finger systolic pressure in the test finger at $15^{\circ} \mathrm{C}$ and $10^{\circ} \mathrm{C}$ as a percentage of the pressure at $30^{\circ} \mathrm{C}$. DPI = digital pressure index in the test finger at $15^{\circ} \mathrm{C}$ and $10^{\circ} \mathrm{C}$, calculated as the ratio of finger systolic pressure to arm systolic pressure)

\begin{tabular}{|c|c|c|c|c|c|c|c|c|}
\hline & \multicolumn{2}{|c|}{$\begin{array}{c}\mathrm{FSP} \%{ }_{15^{\circ}} \\
(\%)\end{array}$} & \multicolumn{2}{|c|}{$\begin{array}{l}\mathrm{DPl}_{15^{\circ}} \\
(\%)\end{array}$} & \multicolumn{2}{|c|}{$\begin{array}{l}\text { FSP } \% 0_{10}^{\circ} \\
(\%)\end{array}$} & \multicolumn{2}{|c|}{$\begin{array}{l}\mathrm{DPI}_{10^{\circ}} \\
(\%)\end{array}$} \\
\hline & Median & Range & Median & Range & Median & Range & Median & Range \\
\hline Referents $(\mathrm{N}=31)$ & 100 & $65-114$ & 93 & $64-104$ & 100 & $61-115$ & 86 & $55-102$ \\
\hline $\begin{array}{l}\text { Chain-saw workers without } \\
\text { VWF }(N=46)\end{array}$ & 100 & $0-124$ & 87 & $0-106$ & 99 & $0-108$ & 85 & $0-102$ \\
\hline $\begin{array}{l}\text { Chain-saw workers with VWF } \\
(N=19)\end{array}$ & 90 & $0-100$ & 77 & $0-100$ & 39 & $0-100$ & 31 & $0-94$ \\
\hline $\begin{array}{l}\text { Patients with primary } \\
\text { Raynaud's phenomenon } \\
(\mathrm{N}=20)\end{array}$ & $55^{\star}$ & $0-80$ & $48^{\star \star *}$ & $0-65$ & $0^{\star \star *}$ & $0-62$ & $0^{* * *}$ & $0-48$ \\
\hline
\end{tabular}

* $P<0.05,{ }^{* \star} P<0.01,{ }^{* * *} P<0.001$ (Kruskal-Wallis test).

Table 5. Results of the cold provocation test at $15^{\circ} \mathrm{C}$ and $10^{\circ} \mathrm{C}$ for the chain-saw workers affected with vibration-induced white finger (VWF) of mild (stage 1), moderate (stage 2), and severe (stage 3 ) grade. (FSP $\%=$ finger systolic pressure in the test finger at $15^{\circ} \mathrm{C}$ and $10^{\circ} \mathrm{C}$ as a percentage of the pressure at $30^{\circ} \mathrm{C}, \mathrm{DPI}=$ digital pressure index in the test finger at $15^{\circ} \mathrm{C}$ and $10^{\circ} \mathrm{C}$, calculated as the ratio of finger systolic pressure to arm systolic pressure)

\begin{tabular}{|c|c|c|c|c|c|c|c|c|c|c|c|c|}
\hline \multirow{2}{*}{$\begin{array}{l}\text { Chain-saw workers } \\
\text { with VWF }\end{array}$} & \multicolumn{2}{|c|}{$\begin{array}{c}\text { Age } \\
\text { (years) }\end{array}$} & \multicolumn{2}{|c|}{$\begin{array}{l}\text { Exposure time } \\
\text { (years) }\end{array}$} & \multicolumn{2}{|c|}{$\begin{array}{l}\mathrm{FSP} \%_{15^{\circ}} \\
(\%)\end{array}$} & \multicolumn{2}{|c|}{$\begin{array}{c}\mathrm{DPI}_{15^{\circ}} \\
(\%)\end{array}$} & \multicolumn{2}{|c|}{$\begin{array}{l}\text { FSP } \%_{10} \\
(\%)\end{array}$} & \multicolumn{2}{|c|}{$\begin{array}{l}\mathrm{DPI}_{10} \\
(\%)\end{array}$} \\
\hline & Median & Range & Median & Range & Median & Range & Median & Range & Median & Range & $\overline{\text { Median }}$ & Range \\
\hline $\begin{array}{l}\text { Stages } 1-2(N=14) \\
\text { Stage } 3(N=5)\end{array}$ & $\begin{array}{l}54.0 \\
56.2\end{array}$ & $\begin{array}{l}33-59 \\
55-59\end{array}$ & $\begin{array}{l}13.5 \\
26.0^{* *}\end{array}$ & $\begin{array}{r}1.5-26 \\
20-28\end{array}$ & $\begin{array}{l}91.0 \\
87.7\end{array}$ & $\begin{array}{r}62.5-100 \\
0-100\end{array}$ & $\begin{array}{l}80.1 \\
62.5\end{array}$ & $\begin{array}{r}54.1-100 \\
0-91.8\end{array}$ & $\begin{array}{c}44.1 \\
0^{*}\end{array}$ & $\begin{array}{l}0-100 \\
0-40\end{array}$ & $\begin{array}{c}36.1 \\
0^{*}\end{array}$ & $\begin{array}{l}0-94.5 \\
0-30.6\end{array}$ \\
\hline
\end{tabular}

* $P<0.04, * * P<0.02$ (Mann-Whitney test).

nificant decrease in FSP\% and DPI among the chainsaw workers with VWF and the patients with primary Raynaud's phenomenon in comparison with the subjects with no vasospastic symptoms. The patients with primary Raynaud's phenomenon exhibited more powerful digital vasospasm at $10^{\circ} \mathrm{C}$ than the professional chain sawyers with VWF $(\mathrm{P}<0.002)$. A multiple comparison test showed no differences in the change of FSP and DPI between the referents and the chain-saw workers without VWF.

Table 5 shows that the VWF subjects with more severe symptoms (stage 3 ) experienced a stronger peripheral vasoconstriction at $10^{\circ} \mathrm{C}$ than those with mild or moderate symptoms (stage 1 and 2). It is worth noting that age was similar in the two VWF subgroups, while the two subgroups differed significantly with respect to the duration of exposure to vibration. No difference in FSP\% and DPI ${ }_{10^{\circ}}$ was observed between the patients with primary Raynaud's phenomenon and the chain sawyers with stage 3 of VWF. Total closure of the digital arteries during local cooling to $10^{\circ} \mathrm{C}$ (ie, zero blood pressure in the test finger) occurred in five VWF workers (26.3\%) and 15 primary Raynaud's phenomenon patients $(75.0 \%)$. Among the VWF chain sawyers showing the closing phenomenon at $10^{\circ} \mathrm{C}$, four $(80 \%)$ were in stage 3. One chain-saw worker with peripheral sensorineural disturbances alone had zero pressure in the finger at both 15 and $10^{\circ} \mathrm{C}$, a finding indicating a preclinical condition of Raynaud's phenomenon. When age and tobacco consumption were allowed for, FSP ${ }_{10^{\circ}}$ was found to be inversely related to the duration of exposure to vibration among the chain sawyers $(P=0.003)$.

\section{Sensitivity, specificity and predictive value} of the cold test

The sensitivity and specificity of the cold test to detect digital vasospasm in Raynaud's phenomenon was assessed with the use of FSP ${ }_{10}<60 \%$ as the discriminating threshold between normal and pathological responses of the digital arteries to cold provocation (table 6). Abnormal cold reactions in the digital vessels were observed in none of the referents (specificity among the unexposed referents being $100 \%$ ) and in one chain sawyer without VWF (specificity among the "exposed" referents being $97.8 \%$ ). Three workers affected with VWF and one patient suffering from primary Raynaud's phenomenon showed falsely negative results (ie, normoreactivity to cold with Raynaud's symptoms), a finding indicating that the sensitivity of the cold test was 84.2 and $95.0 \%$, respectively. In the diagnosis of VWF, the predictive value of a positive test $\left(\mathrm{FSP} \%_{10}<60 \%\right)$ was found to be $94.1 \%$, while the predictive value of a negative test was $93.7 \%$. 


\section{Discussion}

The results of this study indicate that the change in FSP during local cooling to 15 and $10^{\circ} \mathrm{C}$ was similar in normal male subjects aged 20 to 69 years. Therefore, age does not seem to influence the reaction of digital arteries to cold in healthy men. $\mathrm{DPI}_{10^{\circ}}$ was found to be lower in the age range 60-69 years than in the younger age groups. This finding may be ascribed to factors related to both the sample size and the greater increase in arm systolic pressure at $10^{\circ} \mathrm{C}$ observed in the older subjects. Cold-induced vasoconstriction was stronger in the smokers than in the nonsmokers. It has been reported that among VWF workers tobacco users show more severe vasospastic symptoms and an increased hyperreactivity to cold provocation than nonusers (12). These findings suggest that smoking has a harmful effect on digital circulation in both normal subjects and VWF workers.

In this study, the results of the cold test indicated that the variance of $\mathrm{FSP} \%$ at 15 and $10^{\circ} \mathrm{C}$ was smaller than that of the DPI. Since the change in FSP in the cooled finger was corrected for the change in systemic arterial blood pressure, the FSP\% can be considered a more stable pressure parameter than DPI, which closely depends on the variations in arterial systolic pressure during cold provocation. In a previous study of the repeatability of finger systolic pressure measurements (13), it was found that for five normal men tested for five consecutive days the coefficient of variation for repeated determinations of FSP $\%$ at 15 and $10^{\circ} \mathrm{C}$ averaged 6.4 (SD 2.2)\%, a figure lower than the mean value of 7.3 (SD 3.5)\% observed for the corresponding DPI. These findings, as well as the results of other studies $(4,14)$, suggest that FSP\% is a robust and repeatable index of digital circulatory function during cold provocation.

In this investigation, $\mathrm{FSP} \%$ at 15 and $10^{\circ} \mathrm{C}$ could differentiate between patients with VWF and primary Raynaud's phenomenon and other subjects not affected with vasospastic symptoms. Furthermore, the cold test could separate chain-saw workers with mild and moderate forms of VWF (stage 1 and 2) from those with more severe finger blanching attacks (stage 3). In primary Raynaud's phenomenon the cold response of digital arteries was more exaggerated than in VWF. A similar finding has been reported in several studies of Raynaud's phenomenon $(8,15,16)$. Experimental investigations have pointed out a hyperactivity of the central sympathetic nervous system during cold exposure and postural stress in both primary Raynaud's phenomenon and VWF patients $(17,18)$. In a study of the sympathetic vasoconstrictor reflex mechanism in Raynaud's phenomenon (16), primary Raynaud's phenomenon subjects showed an increased vasoconstriction to vibration when compared with VWF workers. It has been suggested that prolonged use of vibrating tools can induce either an adaptation of the central nervous
Table 6. Sensitivity and specificity of finger systolic pressure measurement to detect cold-induced digital arterial hyperresponsiveness in vibration-induced white finger (VWF). The predictive value of the cold test is also reported. (FSP\% = finger systolic pressure in the test finger at $10^{\circ} \mathrm{C}$ as a percentage of the pressure at $30^{\circ} \mathrm{C}, 95 \% \mathrm{Cl}=95 \%$ confidence interval)

\begin{tabular}{|c|c|c|c|}
\hline \multirow[b]{2}{*}{$\begin{array}{l}\text { Diagnostic } \\
\text { criterion }\end{array}$} & \multirow[b]{2}{*}{$\begin{array}{l}\text { Referents } \\
(\mathrm{N}=31)\end{array}$} & \multicolumn{2}{|c|}{ Chain-saw workers } \\
\hline & & $\begin{array}{l}\text { Without } \\
\text { VWF } \\
(N=46)\end{array}$ & $\begin{array}{l}\text { With } \\
\text { VWF } \\
(N=19)\end{array}$ \\
\hline \multicolumn{4}{|l|}{$\mathrm{FSP} \%:<60 \%$ at $10^{\circ} \mathrm{C}$} \\
\hline $\begin{array}{l}\text { Positive } \\
\text { Negative }\end{array}$ & $\overline{31}$ & $\begin{array}{r}1 \\
45 \\
\end{array}$ & $\begin{array}{r}16 \\
3 \\
\end{array}$ \\
\hline \multicolumn{4}{|l|}{ Specificity } \\
\hline $\begin{array}{l}\text { Referents }(\%) \\
\text { Chain-saw workers without } \\
\text { VWF (\%) }\end{array}$ & $\begin{array}{l}100 \\
97.8\end{array}$ & $\begin{array}{l}(95 \% \mathrm{Cl} 88 \\
(95 \% \mathrm{Cl} 88\end{array}$ & $\begin{array}{l}8.8-100) \\
8.5-99.9)\end{array}$ \\
\hline Sensitivity (\%) & 84.2 & \multicolumn{2}{|c|}{$(95 \% \mathrm{Cl} 60.4-96.6)$} \\
\hline VWF prevalence $(\%)$ & 29.2 & \multicolumn{2}{|c|}{ (95\% Cl $18.6-41.8)$} \\
\hline \multicolumn{4}{|l|}{ Predictive value } \\
\hline $\begin{array}{l}\text { Positive test }(\%) \\
\text { Negative test }(\%)\end{array}$ & $\begin{array}{l}94.1 \\
93.7\end{array}$ & \multicolumn{2}{|c|}{$\begin{array}{l}(95 \% \text { Cl } 71.3-99.8) \\
(95 \% \text { Cl } 82.8-98.7)\end{array}$} \\
\hline
\end{tabular}

system to vibration or a peripheral sensory neuropathy which attenuates, at least partially, the vasoconstrictor response of the digital arteries in VWF workers $(15,16,19)$. However, the results of the present study indicate that the augmented vascular reactivity to cold in the primary Raynaud's phenomenon group, compared with the VWF group, may also have been due to differences in the clinical stage of the vasospastic syndrome, as cold-induced digital arterial hyperresponsiveness was not found to be significantly different between the patients with primary Raynaud's phenomenon and the vibration-exposed workers with severe VWF symptoms. It has been reported that vibration-exposed workers may exhibit an abnormal digital arterial cold response before the appearance of VWF symptoms (4). In this investigation, the closing phenomenon of the digital arteries was observed in one chain-saw worker with a negative history of finger blanching attacks. This finding confirms that FSP measurement during local cooling is useful in disclosing peripheral vascular hyperreactivity in vibration-exposed workers without subjective Raynaud's symptoms.

In this study, a lower normal limit of $75 \%$ for FSP $\%_{15^{\circ}}$ failed to discriminate on an individual basis in the vibration-exposed group because of a high proportion of falsely negative results among the chain sawyers with VWF (84\%). On the contrary, the sensitivity of the cold test at $15^{\circ} \mathrm{C}$ was satisfactory for the primary Raynaud's phenomenon group (86.3\%). It is likely that local cooling to $15^{\circ} \mathrm{C}$ is not a sufficient cold stimulus to provoke digital vasospasm in VWF workers, mainly among those with mild or moderate vasospastic symptoms. The analysis of the ROC curve for FSP ${ }_{10^{\circ}}$ showed that a value of $60 \%$ was the optimal threshold with which to 
obtain a high true positive fraction (sensitivity) and a negligible false positive fraction (1-specificity) in both the primary Raynaud's phenomenon and VWF groups. It is worth noting that the discriminating threshold of FSP $\%{ }_{10}<60 \%$ is in close agreement with the lower limit found for the normal population examined in this study (63\%). Moreover, the proposed threshold is also consistent with those suggested by other authors who reported lower normal limits of $59-66 \%$ at $10^{\circ} \mathrm{C}$ in smaller samples of male referents $(5,7,20)$.

Olsen et al (4) have suggested the rigid criterion of zero pressure (closing phenomenon of the digital arteries) to diagnose Raynaud's syndrome. They considered that both local and body cooling are needed to provoke a complete digital vasospasm in Raynaud patients. In this study body cooling was not performed owing the lack of consent by most referents and vibration-exposed workers who felt the procedure was uncomfortable. However, the findings of this investigation and clinical experience suggest that the diagnostic criterion adopted (FSP\% ${ }_{10^{0}}<60 \%$ ) is sufficiently strict to detect abnormal cold response in the digital arteries of most subjects with a true history of primary Raynaud's phenomenon or VWF. This opinion seems to be supported by the results reported in table 6 regarding the efficiency of the cold test to diagnose Raynaud's phenomenon objectively in a group of chain sawyers with a known VWF prevalence. The discriminating threshold of FSP $\%_{10^{\circ}}<60 \%$ appears to be an appropriate diagnostic criterion to reveal VWF, as in the chain-saw group the predictive value of a positive test - denoting how often the cold test was correct when its result was positive - was as high as $94 \%$. A similar figure was observed for the predictive value of a negative test (ie, correctness of negative results).

In conclusion, the findings of this study suggest that the change in FSP during standardized cold provocation at $10^{\circ} \mathrm{C}$ is a useful laboratory test to differentiate between healthy subjects and patients with primary Raynaud's phenomenon or VWF both on a group basis and on an individual basis. Therefore the pressure parameter $\mathrm{FSP} \%{ }_{10^{\circ}}$ can be used not only in epidemiologic surveys, but also for medicolegal problems and insurance compensation purposes.

\section{References}

1. Nielsen SL, Lassen NA. Finger systolic pressure in upper extremities testing for cold sensitivity (Raynaud's phenomenon). In: Bernstein EF, ed. Noninvasive diagnostic technique in vascular disease. London: CV Mosby Company, 1982:410 - 6 .

2. Olsen N, Nielsen SL. Prevalence of primary Raynaud phenomena in young females. Scand J Clin Lab Invest $1978 ; 37: 761-4$.
3. Kurosawa $Y$, Nasu Y, Oshiro H. Finger systolic blood pressure measurements after finger cooling: using the laser-Doppler method for assessing vibration-induced white finger. J Occup Med 1992;34:683-6.

4. Olsen N, Nielsen SL, Voss P. Cold response of digital arteries in chain saw operators. Br J Ind Med 1982; $39: 82-8$.

5. Lagerkvist B, Linderholm $\mathrm{H}$, Nordberg GF. Vasospastic tendency and Raynaud's phenomenon in smelter workers exposed to arsenic. Environ Res 1986;39: 465-74.

6. Milford Ward A, Udnoon S, Watkins J, Walker AE, Darke CS. Immunologic mechanisms in the pathogeneneis of vinyl chloride disease. Br Med J 1976;1:9368.

7. Ekenvall L, Lindblad LE. Vibration white finger and digital systolic pressure during cooling. $\mathrm{Br} \mathrm{J}$ Ind Med $1986 ; 43: 280-3$.

8. Virokannas H, Rintamäki H. Finger blood pressure and rewarming rate for screening and diagnosis of Raynaud's phenomenon in workers exposed to vibration. Br J Ind Med 1991;48:480—4.

9. Gemne G, Pyykkö I, Taylor W, Pelmear PL. The Stockholm Workshop scale for the classification of cold-induced Raynaud's phenomenon in the hand-arm vibration syndrome (revision of the Taylor-Pelmear scale). Scand J Work Environ Health 1987;13:2758.

10. Allen EV, Brown GE. Raynaud's disease: a critical review of minimal requisities for diagnosis. Am J Med Sci 1932;183:187-200.

11. Nielsen SL, Lassen NA. Measurement of digital blood pressure after local cooling. J Appl Physiol 1977; 43:907-10.

12. Ekenvall L, Lindblad LE. Effect of tobacco use on vibration white finger disease. J Occup Med 1989;31: $13-6$.

13. Bovenzi M. Finger systolic pressure during local cooling in normal subjects aged 20 to 60 years: reference values for the assessment of digital vasospasm in Raynaud's phenomenon of occupational origin. Int Arch Occup Environ Health 1988;61:179-81.

14. Carnicelli MVF, Griffin MJ, Rice CG. Repeatability of finger systolic blood pressure and finger rewarming. In: Abstracts of the 6th International Conference on Hand-Arm Vibration, May 1992. Bonn: Berufsgenossenschaftliches Institut für Arbeitssicherheit, 1992:21.

15. Olsen N, Hansen SW. Vasomotor functions of skin microcirculation in vasospastic Raynaud's phenomena. Acta Physiol Scand 1992;43 suppl 603:101-7.

16. Olsen N, Petring OU. Vibration elicited vasoconstrictor reflex in Raynaud's phenomenon. $\mathrm{Br} \mathrm{J}$ Ind Med 1988;45:415-9.

17. Olsen N, Petring OU, Rossing N. Exaggerated postural vasoconstrictor reflex in Raynaud's phenomenon. $\mathrm{Br}$ Med J 1987;294:1186-88.

18. Olsen N, Fjeldborg P, Brøchner-Mortensen J. Sympathetic and local vasoconstrictor response to cold in vibration induced white finger. $\mathrm{Br} \mathrm{J}$ Ind $\mathrm{Med}$ $1985 ; 42: 272-5$.

19. Hyvärinen J, Sakata H, Talbot WH, Mountcastle VB. Neuronal coding by cortical cells of the frequency of oscillating peripheral stimuli. Science 1968;162: $1130-2$.

20. Nielsen SL, Sørensen CJ, Olsen N. Thermostatted measurement of systolic blood pressure on cooled fingers. Scand J Clin Lab Invest 1980;40:683-7.

Received for publication: 7 January 1993 